\title{
15 CONDUCTING CRITICAL RESEARCH IN INFORMATION SYSTEMS: Can Actor-Network Theory Help?
}

\author{
Ela Klecuń \\ London School of Economics and Political Science
}

\begin{abstract}
This paper considers the proposition that actor-network theory (ANT) might be adopted within a broader critical paradigm to conduct empirical studies. The paper outlines the main tenets of the two theories, with the critical perspective primarily represented by Foucault. The aim is not to provide an extensive discussion of critical theory and ANT but to focus on their approach to the nature, scope, and level of empirical studies, particularly in their treatment of micro/macro analysis. The paper concludes that the differences are less significant than it may appear at first and that some of ANT's ideas are close to Foucault's position. However, ANT focuses on actors and their actions as they are performed in a particular time and place and does not appear to be concerned to what extent they may be historically conditioned. Thus, ANT on its own, in the view of the author, might not offer sufficient explanations as to why the actors under study take particular actions and why some actors are excluded or marginalized from the innovation process, e.g. from the development and implementation of an IS. For these reasons this paper suggests a critical research agenda enriched by ANT insights.
\end{abstract}

Keywords: Critical theory, actor-network theory, information systems, Foucault

\section{INTRODUCTION}

The Information Systems field is influenced by a number of disciplines, including computer science, management and organizational studies, social science, and philosophy. Early on, many IS researchers primarily concentrated on technology, seeing technological development as following a predefined trajectory and technology as 
driving organizational change (Orlikowski 1992) and the majority of (published) IS research reflected a positivistic orientation (Orlikowski and Baroudi 1991). The IS discipline has significantly moved from this position, with interpretative research becoming more and more popular (Avgerou 2000; Walsham 1995). This broadening of IS research has been long on the agenda of IFIP 8.2, and is illustrated by varied contributions drawing on diverse social theories presented at the conferences since 1984 .

More recently, an approach (or rather approaches) based on critical theory have been adopted by a growing (although still somewhat limited) number of researchers (Doolin and Lowe 2002; Hirschheim and Klein 1989, 1994; Jonsson 1991; Lyytinen 1992; Lyytinen and Klein 1985; Myers and Young 1997; Ngwenyama 1991; Saravanamuthu and Wood-Harper 2001; Wilson 1997).

Lately, some researchers from the IS and management fields called for broadening of the definition of critical research and for more empirically oriented studies (Alvesson and Deetz 2000; Brooke 2002a, 2002b; Doolin and Lowe 2002). Broadening the definition of critical research means including theorists who do not necessarily follow the Frankfurt School tradition. For example, the genealogical writings ofFoucault, poststructuralist deconstruction associated with Derrida, and postmodernist work by Foucault and Lyotard (Kincheloe and McLaren 1994). To this list Brooke (2002a) also adds critical system thinking, critical realism, and critical postmodernism.

Yet, these calls for pluralism raise issues of paradigm incommensurability and diluting of emancipatory principles. While I agree that calling everything critical is unhelpful and indeed will dilute emancipatory principles, I do believe that critical theory should open itself up to new theoretical perspectives. After all, one of the fundamental tenets of critical theory is its need for self-reflexivity and self-critique. Thus, when considering what it means to be critical in IS research, I agree with Brooke (2002b) that it is the emancipatory interest rather than the detailed following of any one particular theorist that is important, providing that the underlying theoretical values and assumptions are explicated and, I would add, providing they are not incommensurable.

Nevertheless, adopting a critical approach poses two problems for IS researchers, namely the need to give attention to information and communication technology (ICT) and the difficulty of conducting empirical research. Critical theory is not specifically concerned with ICT and many, even contemporary works, remain vague on this subject. Critical theory is almost silent with respect to the use of techniques of investigation and does not prescribe how research should be conducted (Morrow and Brown 1994). In order to bridge the gap between philosophical foundations and empirical research, increasingly IS researchers are reaching out to other theories for additional insights, and actor-network theory (ANT) is becoming particularly popular (Doolin 1998; Doolin and Lowe 2002; Whitley 1999a).

This paper evaluates ANT as a good candidate to guide empirical studies within a broader critical paradigm, particularly as represented by Foucault. In doing so, the paper hopes to open a dialogue between often-separate communities of theorists and researchers representing these approaches. The paper's aim is not to provide an extensive discussion of critical theory and ANT but to focus on their approaches to empirical studies and the treatment of micro and macro levels of analysis.

The paper starts by outlining the main concepts of critical theory, focusing on works by Foucault. Then, it considers the proposition that ANT could be adopted for con- 
ducting critical empirical research. In doing so, the paper outlines the main arguments about similarities and differences of the two approaches, focusing on their treatment of the scope of empirical research and the level of analysis. The concluding section summarizes the main points of the discussion, again posing and addressing the question about the applicability of ANT to critical theory-led studies.

\section{THEORETICAL PERSPECTIVES: CRITICAL THEORY AND ANT}

\subsection{Aspects of Critical Theory}

Critical theory is not a unified theory but rather a set of loosely linked principles. It has many flavors and proponents. The central idea in critical theory is that all social phenomena are historically created and conditioned (Horkheimer 1972b; Horkheimer and Adorno 1972). Critical theory has evolved over time, often in response to historical conditions of the time. The early proponents of critical theory from the Frankfurt School sought to develop a historically grounded social theory that could help to transform the world (Held 1980). They produced grand narratives of emancipation, maintaining that social conditions, often constraining emancipation and limiting peoples' potential, are created and recreated by man. They claimed that the consciousness of man is dominated by the ideological superstructures and these may result in alienation. Their aim was to expose and undermine the status quo.

Among second generation theorists, Habermas is perhaps best known, especially in the IS community. Although, Habermas' roots are in the Frankfurt School, his writings have developed many concepts further and taken them in different directions. Habermas seeks to incorporate central notions of the hermeneutic tradition within the bounds of critical philosophy and his works are often seen as an extension of hermeneutics (Jerald 1990). His main concerns are the problems regarding the nature of communication and self-consciousness and their role in the causation of social action (Habermas 1972, 1979). In terms of macro and micro division, Habermas can be seen as leaning toward a macroscopic view of social order but he is also concerned with many microsociological concepts (e.g., speech performances) (Knorr-Cetina 1981).

Casting our net further away from the Frankfurt School, we could also consider theorists from the French school of thought (for example, Foucault, Derrida, and Lyotard) as well as Giddens as working in a critical tradition. This suggestion is a result of our wider, more inclusive definition of a critical tradition that focuses on emancipatory interest. However, can Foucault's work be described as having such an interest? We can argue that by providing a critique of the status quo Foucault undermines the inevitability of the present situation and opens up avenues for change. His genealogical method aims to expose mechanisms of power and to emphasize the contingency and fragility of the circumstances that have shaped present practices. Thus, such an approach has an emancipatory intent. Foucault clearly stated his aim during a television program titled “Human Nature: Justice versus Power" discussed in Rabinow (1984, p. 6). 
[The] real political task in a society such as ours is to criticize the working of institutions which appear to be both neutral and independent; to criticize them in such a manner that the political violence which has always exercised itself obscurely through them will be unmasked, so that one can fight them.

Increasingly, Foucault's works (particularly his later works) are considered as belonging to the critical tradition (Brooke 2002a; Kincheloe and McLaren 1994; McGrath 2003a), and this is a position taken in this paper.

This paper is interested in Foucault's writings for a number of reasons. First, although Foucault's works are detailed, historically situated accounts of different phenomena that do not aspire to produce grand theories of society, their relevance is enduring (refer, for example, Foucault 1979). Indeed, it is through such a micro approach that we can learn about the macro order (Knorr-Cetina 1981).

Second, Foucault focuses on understanding knowledge and power, two concepts I consider as key to the study of information systems. The basic claim of Foucault's genealogy ofknowledge is that political power and scientific knowledge are not external to one another, and thus "regimes of truth" (truth claims in science) have political character (are characterized by power/ knowledge relations present in the scientific discourse of a particular discipline). Foucault (1979) argues that power is not necessarily bad or top-down but is relational, that it is exercised through a net-like organizations. He breaks away from the Enlightenment belief in reason, absolute truth, and totality. To some extent, so do the other critical theorists (Horkheimer and Adorno 1972) but Foucault also eschews grand narratives and emphasizes the importance of the local relations and actions. He rejects an idea of absolute or transcendental truth "outside of history" as well as of any conception of objective or necessary interests that would ground either knowledge, morality, or politics (Olssen 1996).

I believe that it is ontologically and epistemologically feasible to consider complementing a Foucauldian approach with ANT's concepts (discussed in section 3). Indeed, the influence of Foucault on ANT is acknowledged by Law (1986), who states that the concepts of translation in ANT "owe more than a little to the writing of Foucault."

What is central to this paper is Foucault's discussion of modes of analysis. He proposes a genealogical approach that aims to account for the constitution of knowledge, discourses, and domains of objects, without appeal to transcendental subjects (Foucault 1980). In another work, he elaborates the nature of criticism.

Criticism is no longer going to be practiced in the search for formal structures with universal value, but rather as an historical investigation into the events that have led us to constitute ourselves and to recognize ourselves as subjects of what we are doing, thinking, saying. In this sense the criticism is not transcendental and its goal is not of making a metaphysics possible: it is genealogical in its design and archaeological in its method (Foucault 1984, pp. 45-46).

While Foucault alerts us to the diversity of forms and locations of power, he comes under criticism because of his lack of treatment (or inadequate treatment) of structures, the state, the school, the bureaucracy, and their relevance to the notion of power (Olssen 
1996). However, as McGrath (2003b) argues, this neglect is not an inherent feature of his perspective but rather it is due to narrow interpretation of his work that does not take into account his concern with bio-power, as a normalizing and regulatory force working on whole populations. Thus, it could be argued that Foucault's theoretical conceptualizations (spanning both ontology and epistemology) might guide research (including IS research) that aspires to focus on the local, contingent, and negotiated nature of technological innovations without neglecting a broader political and economic context.

Nevertheless, Foucault (and for that matter Habermas) does not explicitly consider ICT in his work. This poses great difficulty for the IS researcher looking for a firm theoretical and methodological ground on which to place an enquiry. This is not to say that critical theory has nothing to say about the technology in general. For example, the relationship between technology and society is discussed by Winner (1977), who sees technology as augmenting, as having accumulative impacts that make some choices increasingly difficult. Ellul (1964) presents a more pessimistic, or fatalistic, account of technology (understood in a broad sense that includes technological artefacts and techniques), warning us that a process of technological change is self-generating, self-determining, and inevitable. On the other hand, Feenberg (1991), and before him Marcuse (1970), consider a technology not as autonomous but as an instrument of social control placed in the hands of the vested interests that control society. In Feenberg's words, "technology is not a destiny but a scene of struggles. It is a social battlefield, or perhaps a better metaphor would be a parliament of things on which civilization's alternatives are debated and decided" (1991, p. 14). Feenberg (1988) believes that we can construct a solution that avoids the excess of both utopian technophobia and uncritical acceptance of given technology as fate. He articulates this as the need to contextualize technologies taking into account more and more of the essential features of the object, bringing together its many dimensions.

Yet, critical theory comes under scrutiny because of the (perceived) dichotomy between theory and practice (Asaro 1999). I would argue that this dichotomy is not embedded in critical theory; on the contrary, critical theory sees action as an extension of theory. Thus, it is important that critical research continues to move beyond purely theoretical endeavors. Alvesson and Willmott (1992) and Alvesson and Dietz (2000) similarly argue that in the field of management it is essential to close the gap between theory and practice.

\subsection{Critical IS Research}

In 1992, Lyytinen appraised the state of critical IS research, pointing out its limitations, and outlining its general requirements.

In order to move from fragmentary critical IS research to systemic "praxis"oriented research, future studies should change their goals and research content. The inquiry needs to shift from critique into more concrete and problem-focused studies of the implications of Critical Theory for IS....In this research model, critical inquiry is concerned with the improvement of the human condition through IS, criticism of alienated and distorted practices, 
development of alternative IS forms and organizations, and with finding and enclaving an arena for emancipatory IS activity (Lyytinen 1992, pp. 171-172).

The call for systemic praxis-oriented research that is concrete and problem-focused has been taken up by a (small, so far) number of IS researchers (Cecez-Kecmanovic et al. 2002; Howcroft and Wilson 1999; McAulay et al. 2002; Myers and Young 1997; Oliver and Romm 2002; Waring 1999).

The paucity of critical theory-driven research in IS, in my opinion, is not only due to the neglect of ICT in critical theorists' writings, but also because critical theory is a meta-theory, built from a collection of many writings on different subjects. It does not prescribe specific methods for empirical research or offer detailed guidelines to follow. This poses difficulty for the researcher in terms of how to conduct the research and how to judge its quality. These problems have been tackled by a number of contemporary authors (Alvesson and Deetz 2000; Alvesson and Skoldberg 2000; Kincheloe and McLaren 1994; Morrow and Brown 1994). For example, Guba and Lincoln (1994) provide the following criteria for judging the goodness or quality of inquiry: first, its historical situatedness (i.e., that it takes account of the social, political, cultural, economic, ethnic, and gender antecedents of the studied situation); second, the extent to which the inquiry acts to erode ignorance and misapprehension; third, if and to what extent it spurs people to action, that is, to the transformation of the existing structure. These criteria are hard to satisfy and moreover they are very subjective.

Within the IS field a concern has been voiced that researchers, in their drive to account for organizational, social, and political factors, have neglected the technology itself, treating it as a black box, for example, not considering different parts of an IS, like software, standards, procedures, rules, and work activities (Monteiro 2000; Orlikowski and Iacono 2001). Similarly, Williams and Edge (1996) argue that a useful theory of the relationship between technology and society needs to address more directly the characteristics of the material world.

How might the IS researcher conduct a study that is all of the following: informed by a social theory, in our case critical theory, and taking into consideration different macro trends but also focused on the local; eschewing grand narratives and a priori classifications but also rejecting relativism; sensitive to social, political, and economic factors but also not forgetting or black boxing the technology itself?

Considering the dilemma facing empirical researchers, Feenberg (1999, p. 13) suggests

we can fruitfully combine modernity theory and technology studies in an empirically informed, critical approach to important social problems. The triviality that threatens a strictly descriptive, empirical approach to such humanly significant technical phenomena as experimentation on human subjects, nuclear power, or the development of the automobile, can be avoided without falling into the opposite error of a priori theorizing. The alternative-global condemnation, narrow empiricism-is not exhaustive. There are ways of recovering some of the normative richness of the critique of modernity within a more concrete sociological framework that does allow entry to a few facts. 
Fully agreeing with this statement, this paper suggests that critical theory can help to preserve the normative richness of the critique of modernity while actor-network theory offers a more concrete sociological framework. Indeed, such an approach has already been proposed by a number of IS researchers. For example, Whitley (1999a) suggests that the principles of critical theory can be applied to the study of IS by drawing on the work of Bruno Latour (one of the main theorists of ANT). Mitev (2003) advocates using social constructivism and ANT as the basis for a critical analysis, Monteiro (2000) suggests that ANT lends itself to empirically underpinned studies. Doolin and Lowe (2002) argue that ANT, as its stands, is well suited to conducting empirical IS research within a broader critical research project. Specifically, they claim that "actornetwork theory offers a particularly effective 'alternative reading' of social interactions within organizations through its emphasis on empirical enquiry and its lack of constraining structure and ontology" (p. 72). Before the suitability of ANT for critical empirical research can be considered, its main concepts need to be outlined.

\subsection{An Introduction to Actor-Network Theory}

ANT rejects any a priori distinction between technology and society, proposing that both should be studied in the same way, through the same (or interchangeable) language and metaphors. In ANT terms, innovations are developed and adopted (or not) through the building of networks of alliances between human and nonhuman actors (Monteiro 2000). The sociology of translation, an important concept in ANT, expresses how innovations are translated or constructed and transposed from one state to another, and how different actors may be co-opted (enrolled) to support a particular innovation or project within a heterogeneous network of actors (Callon 1986). For a network to succeed or be sustained, such a transformation must become stable (stronger), even irreversible, but this stability is often difficult to sustain.

ANT might be conceptualized as both a theory and a methodology. However, as Latour tells us, ANT does not tell us positive things about the world (i.e., how the social world is) but rather suggests how to study things (Latour forthcoming). What does ANT say about conducting an empirical study? Its advice is simple: follow the actors. Only by following actors, their actions, and interactions can we say something about the situation. This means that no a priori expectations or theoretical concepts should guide, or rather limit, our research. For example, we should not make a priori distinction "between the size of actors, between the real and the unreal, between what is necessary and what contingent, between the technical and the social" (Callon and Latour 1981, pp. 291 -292). According to Latour (forthcoming), "actors themselves make everything, including their own frames, their own theories, their own contexts, their own metaphysics, even their own ontologies." Thus, in commenting on how to write research findings, he tells us not to impose our own frameworks or concepts but just describe. It is a thick description that provides insights into the situation.

Typically, ANT informed research would start by identifying key actors, interests, and scenarios, and then trace them over time (Monteiro and Sahay 2000), but it is difficult for the researcher to know when to stop (i.e., where to draw the boundary of the study). Ultimately, there is no prescription on how to do it and such a process is somewhat arbitrary. 
Is there anything more to the methodology of ANT? No... and yes. No, because there are no frameworks or steps to follow. Yes, because ANT provides us with certain concepts that we may find helpful while conducting research. For example, ANT elaborates on the processes of construction and deconstruction of actor networks in terms of four moments of translation (or phases): problematization, interessement, enrolment, and mobilization (Callon 1986). It also, through examples, describes how interests and expectations may be inscribed in actors (e.g., in an information system).

ANT is gaining popularity in IS research, partly because, through its theoretical concepts and language, it supports the researcher in being more specific about technology (e.g., through inscriptions). ANT offers a way for describing how technical design and systems are interwoven with organizational issues (Monteiro and Hanseth 1996). Furthermore, as ICT becomes more ubiquitous and embedded in our everyday activities, "we need new methodological and theoretical devices to enable us to think about hybrids of people and information technology" (Walsham 1997). ANT seems to offer just this.

However, ANT has been accused of being apolitical, lacking an evaluative stance that might help people judge the possibilities presented by the technology and consider the consequences, and not taking into account that there may be dynamics evident in technological change beyond those revealed by studying the immediate needs, interests, problems, and solutions of specific groups (Walsham 1997; Winner 1993). This is significant if we are concerned with emancipatory principles and suggest ANT as a way of operationalizing critical theory. ANT in particular, because of its symmetrical treatment of humans and nonhumans and the definition of action as distributed through different entities (human and nonhuman) in socio-technical ensembles, is open to a charge ofdiluting intentionality, responsibility, and accountability (Latour 1999; Stalder 2000). Furthermore, although ANT rejects a priori assignment of motives to actors, it can be argued that implicitly it presumes that actors are rational and goal-oriented. There is a danger that the strategic and rational aspects of ANT become over-emphasized in IS studies (Monteiro and Sahay 2000). In order to combat perceived shortcomings of ANT, in particular its neglect of influences of structures on micro-events and processes, a number of writers proposed an approach that combines ANT with ideas from other social theories (Avgerou 2002; Walsham 1997; Whitley 1999b).

Thus we see that calls to combine the critical tradition with ANT come from two quarters: those who see ANT as the overriding theory but benefitting from adopting additional insights and concepts (e.g., regarding power) and those who search for other theories, including ANT, to assist with empirical critical studies in IS.

\section{CRITICAL THEORY AND ACTOR-NETWORK THEORY: CAN THEY COMPLEMENT EACH OTHER?}

The previous section briefly introduced critical theory and ANT and their application in the IS field, noting that arguments have been voiced for basing IS research on both approaches (combined in some way). This section considers whether ANT can complement critical theory and enrich empirical studies in the IS field. In doing so, this 
section revisits some of the ontological and epistemological assumptions behind the two theories and considers to what extent, if any, they are compatible. Specifically, this section considers their position regarding macro and micro levels of analysis.

Burrell and Morgan (1985) consider critical theory as having much in common with the interpretative paradigm. They categorize critical theory as belonging to a radical humanism paradigm, placed between the subjective and the sociology of radical change axis in their framework. But increasingly, critical approaches incorporate different ontological and epistemological assumptions and exhibit methodological pluralism (Brooke 2002a). It is not the aim of this paper to discuss the pros and cons of methodological pluralism (Mingers 2001) or the relative merits ofdifferent perspectives within the critical tradition; that has been done by others (Brooke 2002a; Fitzgerald and Howcroft 1998). Here, I aim to highlight the diversity of traditions within the broadly understood critical perspective. Such diversity at least allows us to consider the possibility of incorporating (redefined?) ANT within a critical perspective.

ANT is often seen as belonging to the social constructivism tradition, and is thus used as a lens in interpretative IS research (Cordella and Shaikh 2003). This would imply that it has constructivist (relativist) ontology and interpretative epistemology, not unlike critical theory as espoused by the Frankfurt School. However, as mentioned earlier, critical theory is not a uniform theory, and Foucault's later works are seen by some as adopting a more realist position (i.e., being based on objectivist ontology) (Olssen 1996). This would suggest that Foucault's works and ANT are based on different ontological and epistemological assumptions and, if one subscribes to incommensurability of paradigms, as being incompatible. However, Latour rejects the assumption that ANT is based on constructivist ontology. Cordella and Shaikh (2003) argue that ANT has its own ontology, that it sees reality as emerging from interactions between different actors. Such an understanding of ANT would bring it closer to Foucault's critical research. Furthermore, such clear paradigm distinctions are seen as unhelpful by some (Allen and Ellis 1997; Alvesson and Deetz 2000; Fitzgerald and Howcroft 1998). Thus, I would argue, critical theory and ANT are not incommensurable and can potentially complement each other in IS research.

In conducting an empirical study, a critical researcher is faced with an important choice regarding the unit of analysis in terms of the application of emancipatory principle. Should the focus be on emancipation within organizational boundaries or, alternatively, consider how critically informed research could influence wider society? The choice of either of these models has implications for the contributions expected, and certainly the second type of research seems more difficult. Although it is customary in IS research to focus on one unit of analysis, consideration of multiple units of analysis is important for capturing different perspectives. As Markus and Robey (1988 p. 596) note, "By consciously mixing levels of analysis, researchers can explore the dynamic interplay among individuals, technology, and larger structures." From critical theory perspective Horkheimer (1972a, p. 249), commenting on critical theory, proclaims that "The theory is concerned with society as a whole." Morrow and Brown (1994) argue that a good critical research even if focusing on a particular level of enquiry should remain aware of other levels and their influence on the research area. This means that when conducting an analysis of, for example, an implementation of IS in one organization, when analyzing local dominant discourses and situated action, we need to take into 
consideration wider structures that may be constraining (and enabling) such actions, and influencing their consequences (i.e., class, gender, ethnicity, and so on). Indeed, many of the strands of critical theory (e.g., the Frankfurt School and feminism) consider as $a$ priori certain superstructures and their influence on local circumstances. Although this is not true of Foucault's writings, it does not mean that he neglects macro structures. He is, however, against the search for an organizing principle and an explanation of all phenomena in relation to a single center (Olssen 1996). He sees history as subject to discontinuities, segmentations, and different types of relations, and maintains that there are no simple material categories (e.g., class) that explain everything. Such a perspective lends itself to empirical (but reflective) studies of local phenomena.

ANT offers a somewhat different view on the micro-macro relationship. It promotes a uniform framework regardless of the unit of analysis and it refuses to distinguish $a$ priori between small and big networks (Callon and Latour 1981; Monteiro 2000). Furthermore, it refuses to assign a priori attribution of social interests. Latour's position that the analysis of networks suffices and that the introduction of macro-social terms would obscure the activities of the underlying actors may appear contrary to the critical theory position, particularly as espoused by the Frankfurt School. ANT suggests that it is the actors that establish (interpret and make real) the macro trends (e.g., capitalism) and thus we should not create an artificial distinction between the local and the global but that we can extend a study to ever-wider actor-networks.

This approach is criticized for its flat ontology (Monteiro 2000), and Feenberg (1999) argues that Latour reduces the terms society and nature to local actions. Furthermore, starting with actors involved with an innovation, and not referring to the traditional categories of social theory, such as class, culture, and the state, means we might not be aware of or even concerned about actors (or potential actors) who are missing. We may not be able to explain why they might have been excluded or marginalized (Feenberg 1999; Williams and Edge 1996). As Feenberg (1999) argues, "this means that stronger parties establish the definition of basic terms, culture, nature and society, and there is no appeal to a priori essence" and thus ANT contains an implicit bias toward victors (Radder 1996).

So far, this section outlines a number of important points regarding ANT's position. The reminder of the section reconsiders these one by one and examines to what extent ANT's position is (or could be) compatible with critical theory proponents. First, I stated that ANT refuses to assign a priori motives to actors (e.g., that managers are interested in IS only in terms of their potential for efficiency gains). However, this does not mean that ANT disregards motives or assumptions but these should be uncovered in empirical studies. For example, it doesn't ignore capitalism; it asks where the effects of capitalism can be seen. Thus this point should not be of great contention between critical theory and ANT. Indeed, Foucault does not adopt a priori a political or moral agenda that represents the interests of particular groups. It may be argued, however, that having in mind some a priori assumptions or rather suspicions (e.g., that women might be marginalized) facilitates focus on potential conflicts and mistrust of the taken-forgranted facts. Yet, such suspicions should be taken as given (as transcendental truths) and a good empirical study should stay open minded with regard to its findings.

The second point, that no a priori differences in macro or micro networks exist, and that researching networks is sufficient, may be understood as proposing that macro- 
structures do not determine micro-events, and that social processes exhibit chains of intended and unintended outcomes (Mitev 2003). Mitev suggests that, "While 'conditions of possibility' [as Knights and Murray (1997) describe external forces] frame organizational behavior, actors construct at the local level the 'external forces' that they respond to." Or in the words of Knights and Murray, quoted in Mitev (2003, p. 35), "a technological opportunity or constraint exists only in so much as people believe it exists."

This is not an interpretation I choose to favor. I agree with Kallinikos (2002) and Avgerou (2002) that the process of construction of technology is not purely local, but is a result of many processes and past experiences, either individual or group, immediate or secondary, that influence local decisions. Using critical theory language, technology is historically situated. But what is ANT's stance on this? My interpretation (based on different relevant readings, in particular Latour [1999]) is that ANT, through empirical studies, links macro and micro. Such linking takes place not just in the construction of the macro by actants (i.e., the micro elements) but rather in studying the relationships between different actants. The process of identifying the local in the global, and vice versa and thus spanning local and global (without making a priori distinctions) involves unpacking seemingly macro-elements down to their empirical constituents and black boxing or collapsing an entire (or a part of an) actor-network into a single actant (Monteiro 2000). Following these steps would lead an IS researcher to encompass "micromacro" perspectives in a study. Micromacro is written here as a one word to emphasize that such an approach rejects the micro-macro dichotomy; it is, however, noted that in practice boundaries of research have to be drawn and some black boxes left unopened. Such an approach would allow us to consider how wider (macro) trends (e.g., anti-trust laws, national security threats, etc.) influence local developments.

Understood in this way, ANT's position brings it closer to the approach advocated by Foucault. It differs, however, in that it is focused on actants and their actions in a particular place and time, eschewing historically based analysis. Thus, I am still left with a charge that following actors does not lend itself to explanations of why some actors take certain actions, or why they do not appear at all or are marginalized. Thus, I would suggest that we do need to bring with us an awareness of class, race, or gender, and how they are historically constituted. However, any a priori assumptions should be open to empirical analysis. Thus I advocate a research agenda based on a critical (Foucauldian) approach with empirical studies enriched by insights from ANT.

\section{CONCLUDING REMARKS}

This paper has indicated some problems facing the critical researcher in IS arising from the fragmented nature of critical theory, its cursory treatment of ICT, and the lack of guidelines on how to conduct critical research. Having in mind these problems, the paper then considered if ANT could assist the IS researcher in conducting critically inspired studies.

The paper suggests that by theorizing the nature of actor-networks and elaborating the theory of translations ANT develops concepts and vocabulary that may assist the IS researcher in investigating, for example, how networks are formed and actors are 
enrolled during early stages of decision-making activities regarding a new information system, and during the system implementation and subsequent use (or non-use). ANT also offers a fresh view on human and technology collectives and indicates how we may treat them. ANT is thus not only a theory but also a research methodology and has the potential to address some of the problems facing the IS researcher who seeks to draw from critical theory.

There are, however, obstacles to combining both theoretical perspectives in research. This paper briefly considered their potential ontological and epistemological differences, concentrating on their treatment of micro and macro levels of analysis. As shown, the differences, although at first appearing to be significant, might not be so. I argue ANT is close to Foucault's perspective in terms of its ontology and epistemology (e.g., both focus on local, situated actions and a rejection of grand narratives).

Yet, I still agree with ANT's critics who argue that a research methodology based on following the actors and a rejection of a priori constructs may lead to results that privilege the views of certain actors and do not consider those who do not immediately appear. As suggested here, Foucault's rejection of grand narratives does not necessarily mean a total rejection of a priori constructs (e.g., the role of the state), but instead it leads us to question such constructs through conducting detailed (we might say geological) studies. Thus, an empirical program for critically led research would aim to question the status quo through detailed studies of how things come to be, for which following the actors would be an excellent start, and also be sensitive to a priori constructs, such as gender, class, or state. Such constructs should not be taken for granted or seen as natural and enduring but act as sensitizers. Empirical study should concentrate on local, situated actions and relationships and see them as historically situated.

The approach proposed here does not claim to combine into a seamless whole critical theory and ANT; rather, it illustrates how ANT might be used as a way of operationalizing critical theory in practice. Thus, the paper illustrates how ANT might help critical research. Conversely we could consider how critical theory concepts may inform ANT research. The paper hopes to open a dialogue between the proponents of these two approaches.

\section{ACKNOWLEDGMENTS}

I would like to thank Tony Cornford, Edgar Whitley, and the reviewers for their very useful comments.

\section{REFERENCES}

Allen, D., and Ellis, D. "Beyond Paradigm Closure in Information Systems Research: Theoretical Possibilities for Pluralism," in R. D. Galliers, S. Carlsson, C. Loebbecke, C. Murphy, H. R. Hansen, and R. O'Callaghan (Eds.), Proceedings of the $5^{\text {th }}$ European Conference on Information Systems, Cork, Ireland: Cork Publishing Ltd., 1997, pp. 737759.

Alvesson, M., and Deetz, S. Doing Critical Management Research, London: Sage Publications, 2000. 
Alvesson, M., and Skoldberg, K. Reflexive Methodology: New Vistas for Qualitative Research, London: Sage Publications, 2000.

Alvesson, M., and Willmott, H. (Eds..) Critical Management Studies, London: Sage Publications, 1992.

Asaro, P. M. "Transforming Society by Transforming Technology: The Science and Politics in Participatory Design," paper presented at the Critical Management Studies Conference, Manchester, 1999 (available online at http://www.mngt.waikato.ac.nz/ejrot/cmsconference/ documents/Information\%20Tech/Pd_cms.pdf).

Avgerou, C. "Information Systems: What Sort of Science Is it?," Omega (28), 2000, pp. 567579.

Avgerou,, C. Information Systems and Organizational Diversity: The Articulation of Local and Global Rationalities, Oxford: Oxford University Press, 2002.

Brooke, C. "Critical Perspectives on Information Systems: An Impression of the Research Landscape," Journal of Information Technology (17:4), 2002a, pp. 271-283.

Brooke, C. "What Does it Mean to Be 'Critical' in IS Research," Journal of Information Technology (17), 2002b, pp. 49-57.

Burrell, G., and Morgan, G. Sociological Paradigms and Organizational Analysis: Elements of the Sociology of Corporate Life, Aldershot, England: Gower, 1985.

Callon, M. "Some Elements of a Sociology of Translation: Domestication of the Scallops and the Fishermen of St Brieuc Bay," in J. Law (Ed.), Power, Action and Belief, London: Routledge \& Kegan Paul, 1986, pp. 196-233.

Callon, M., and Latour, B. "Unscrewing the Big Leviathan," in K. D. Knorr-Cetina and A. V. Cicourel (Eds.), Advances in Social Theory and Methodology: Towards an Integration of Micro- and Macro-Sociologies, Boston: Routledge \& Kegan Paul, 1981, pp. 277-303.

Cecez-Kecmanovic, D.; Janson, M.; and Brown, A. "The Rationality Framework for a Critical Study of Information Systems," Journal of Information Technology (17:4), 2002, pp. 215227.

Cordella, A., and Shaikh, M. "Actor Network Theory and After: What's New for IS Research?," Proceedings of the $1 \mathbf{l}^{\text {th }}$ European Conference on Information Systems, Naples, Italy, 2003.

Doolin, B. "Information Technology as Disciplinary Technology: Being Critical Interpretive Research on Information Systems," Journal of Information Technology (13), 1998, pp. 301 311.

Doolin, B., and Lowe, A. "To Reveal Is to Critique: Actor-Network Theory and Performativity in Critical Information Systems Research," Journal of Information Technology (17:2), 2002, pp. 69-78.

Ellul, J. The Technological Society, New York: Vintage Books, 1964.

Feenberg, A. "The Bias of Technology," in R. Pippin, A. Feenberg, and C. B. Webel (Eds.), Marcuse: Critical Theory and the Promise of Utopia, London: MacMillan Education, 1988, pp. 225-256.

Feenberg, A. Critical Theory of Technology, New York: Oxford University Press, 1991.

Feenberg, A. "Modernity Theory and Technology Studies: Reflections on Bridging the Gap," paper presented at the Conference on Technology and Modernity, University of Twente, 1999 (available online at http://www-rohan.sdsu.edu/foculty/feenberg/twente.html).

Fitzgerald, B., and Howcroft, D. "Towards Dissolution of the IS Research Debate: From Polarization to Polarity," Journal of Information Technology (13:4), 1998, pp. 313-326.

Foucault, M. Discipline and Punish: The Birth of the Prison, Harmondsworth, England: Penguin, 1979.

Foucault, M. Power/Knowledge: Selected Interviews and Other Writings 1972-77, Brighton, England: Harvest Press, 1980.

Foucault, M. "What Is Enlightenment?" in P. Rabinow (Ed.), The Foucault Reader, London: Penguin Books, 1984, pp. 32-50. 
Guba, E. G., and Lincoln, Y. S. "Competing Paradigms in Qualitative Research," in N. K. Denzin and Y. S. Lincoln (Eds.), Handbook of Qualitative Research, London: Sage

Publications, 1994, pp. 105-117.

Habermas, J. Communication and the Evolution of Society, Boston: Beacon Press, 1979.

Habermas, J. Knowledge and Human Interests, Boston: Beacon Press, 1972.

Held, D. Introduction to Critical Theory: Horkheimer to Habermas, Oxford: Hutchinson \& Co, 1980.

Hirschheim, R., and Klein, H. K. "Four Paradigms of Information Systems Development," Communications of the ACM (32:10), 1989, pp. 1199-1216.

Hirschheim, R., and Klein, H. K. "Realizing Emancipatory Principles in Information Systems Development: The Case for ETHICS," MIS Quarterly (18:1), March 1994, pp. 83-109.

Horkheimer, M. "Postscript," in Critical Theory: Selected Essays of Max Horkheimer, New York: Herder and Herder, 1972a, pp. 244-252.

Horkheimer, M. "Traditional and Critical Theory," in Critical Theory: Selected Essays of Max Horkheimer, New York: Herder and Herder, 1972b, pp. 188-243.

Horkheimer, M., and Adorno, T. W. Dialectic of Enlightenment, New York: Herder and Herder, 1972 (originally published in 1944).

Howcroft, D., and Wilson, M. "Paradoxes of Participatory Design: The End-User Perspective," paper presented at the Critical Management Studies Conference, Manchester, 1999 (available online at http://www.mngt.waikato.ac.nz/ejrot/cmsconference/documents/ Information\%20Tech/Howcroft.pdf).

Jerald, W. The Hermeneutics of life History: Personal Achievement and History in Gadamer, Habermas, and Erikson, Evanston, IL: Northwestern University Press, 1990.

Jonsson, S. "Action Research," in H.-E. Nissen, H. K. Klein, and R. Hirschheim (Eds.), Information Systems Research: Contemporary Approaches and Emergent Traditions, Amsterdam: North-Holland, 1991, pp. 371-396.

Kallinikos, J. "Reopening the Black Box of Technology: Artifacts and Human Agency," in L. Applegate, R. Galliers, and J. I. DeGross (Eds.), Proceedings of the $23^{\text {rd }}$ International Conference on Information Systems, Barcelona, 2002, pp. 287-294.

Kincheloe, J. L., and McLaren, P. L. "Rethinking Critical Theory and Qualitative Research," in N. K. Denzin and Y. S Lincoln (Eds.), Handbook of Qualitative Research, London: Sage Publications, 1994, pp. 138-157.

Knights, D., and Murray, F. "Markets, Managers and Messages: Managing Information Systems in Financial Services," in B. P. Bloomfield, R. Coombs, D. Knights, and D. Littler (Eds.), Information Technology and Organizations: Strategies, Networks andIntegration, Oxford: Oxford University Press, 1997, pp. 36-56.

Knorr-Cetina, K. D. "Introduction: The Micro-Sociological Challenge of Macro-Sociology: Towards a Reconstruction of Social Theory and Methodology," in K. D. Knorr-Cetina and A. V. Cicourel (Eds.), Advances in Social Theory and Methodology: Toward an Integration of Micro- and Macro-Sociologies, Boston: Routledge \& Kegan Paul, 1981, pp. 1-47.

Latour, B. Pandora's Hope: Essays on the Reality of Science Studies, Cambridge, MA: Harvard University Press, 1999.

Latour, B. "On Using ANT for Studying Information Systems: A (Somewhat) Socratic Dialogue," in C. Averou and C. Ciborra (Eds.), Social Study of ICT, Oxford: Oxford University Press, Oxford, Forthcoming.

Law, J. "Editor's Introduction: Power/Knowledge and the Dissolution of the Sociology of Knowledge," in J. Law (Ed.), Power, Action and Belief: A New Sociology of Knowledge, London: Routledge and Kegan Paul, 1986.

Lyytinen, K. "Information Systems and Critical Theory," in M. Alvesson and H. Willmott (Eds.), Critical Management Studies, London: Sage Publications, 1992, pp. 159-180. 
Lyytinen, K. J., and Klein, H. K. "The Critical Theory of Jurgen Habermas as basis for a Theory of Information Systems," in E. Mumford, R. Hirschheim, G. Fitzgerald, and A. T. WoodHaper (Eds.), Research Methods in Information Systems, Amsterdam: North Holland, Amsterdam, 1985, pp. 219-236.

Marcuse, H. One-Dimensional Man, London: Sphere Books Ltd., 1970.

Markus, M. L., and Robey, D. "Information Technology and Organizational Change: Causal Structure in Theory and Research," Management Science (34:5), 1988, pp. 583-598.

McAulay, L.; Doherty, N.; and Keval, N. "The Stakeholder Dimension in Information Systems Evaluation," Journal of Information Technology (17:4), 2002, pp. 241-255.

McGrath, K. "ICTs Supporting Targetmania: How the UK Health Sector is Trying to Modernise," in M. Korpela, R. Montealegre, and A. Poulymenakou (Eds.), Organizational Information Systems in the Context of Globalization, Boston: Kluwer Academic Publishers, 2003a, pp. 19-34.

McGrath, K. Organizational Culture and Information Systems Implementation: A Critical Perspective, Unpublished Ph.D. Dissertation, Department of Information Systems, The London School of Economics, London, 2003b.

Mingers, J. "Combining IS Research Methods: Towards a Pluralist Methodology," Information Systems Research (12:3), 2001, pp. 240-259.

Mitev, N. "Constructivist and Critical Approaches to an IS Failure Case Study: Symmetry, Translation and Power," Working Paper Series, Information Systems Department, London School of Economics, 2003.

Monteiro, E. "Actor-Network Theory and Information Infrastructure," in C. Ciborra (Ed.), Control to Drift, New York: Oxford University Press, 2000, pp. 71-83.

Monteiro, E., and Hanseth, O. "Social Shaping of Information Infrastructure: On Being Specific About the Technology," in W. J. Orlikowski, G. Walsham, M. R. Jones, and J. I. DeGross (Eds.), Information Technology and Changes in Organizational Work, London: Chapman \&Hall, 1996, pp. 325-343.

Monteiro, E., and Sahay, S. "On the Life-Blood of Actants," paper presented at the Latour's Seminar, Troms $\varnothing$, Norway, 2000 (available onine at http://www.idi.ntnu.no/ ericm/ life.blood.htm).

Morrow, R. D., and Brown, D. D. Critical Theory and Methodology, London: Sage Publications, 1994.

Myers, M. D., and Young, L. W. "Hidden Agendas, Power and Managerial Assumptions in Information Systems Development: An Ethnographic Study," Information Technologyand People (10:3) 1997, pp. 224-240.

Ngwenyama, O. K. "The Critical Social Theory Approach to Information Systems: Problems and Challenges," in H.-E. Nissen, H. K. Klein, and R. Hirschheim (Eds.), Information Systems Research: Contemporary Approaches and Emergent Traditions, Amsterdam: North-Holland, 1991, pp. 267-280.

Oliver, D., and Romm, C. "Justifying Enterprise Resource Planning Adoption," Journal of Information Technology (17:4), 2002, pp. 199-213.

Olssen, M. "Michel Foucault's Historical Materialism," in M. Peters, W. Hope, J. Marshall, and S. Webster (Eds.), Critical Theory, Poststructuralism and the Social Context, Palmerston North, New Zealand: Dunmore Press, 1996, pp. 82-105.

Orlikowski, W. J. "The Duality of Technology: Rethinking the Concept of Technology in Organizations," Organization Science (3:3), 1992, pp. 398-427.

Orlikowski, W. J., and Baroudi, J. J. "Studying Information Technology in Organizations: Research Approaches and Assumptions," Information Systems Research (2:1), 1991, pp. 1-28.

Orlikowski, W. J., and Iacono, C. S. "Desperately Seeking the 'IT' in IT Research-A Call to Theorizing the IT Artifact," Information Systems Research (12:2), 2001, pp. 121-134. 
Rabinow, P. "Introduction," in P. Rabinow (Ed.), The Foucault Reader, London: Penguin Books, 1984, pp. 3-29.

Radder, H. In and About the World: Philosophical Studies of Science and Technology, Albany, NY: State University of New York Press, 1996.

Saravanamuthu, K., and Wood-Harper, A. T. "Developing Emancipatory Information Systems," paper presented at (Re-)Defining Critical Research in Information Systems: An International Workshop, The University of Salford, 2001, pp. 91-109.

Stalder, F. "Beyond Constructivism: Towards a Realist Realism. A Review of Bruno Latour's Pandora's Hope," The Information Society (16), 2000, pp. 245-247.

Walsham, G. "The Emergence of Interpretivism in IS Research," Information Systems Research (6), 1995, pp. 376-394.

Walsham, G. "Actor-Network Theory and IS Research: Current Status and Future Prospects," in A. S. Lee, J. Liebenau, and J. I. DeGross (Eds.), Information Systems and Qualitative Research, London: Chapman \& Hall, 1997, pp. 466-480.

Waring, T. S. "The Challenge ofEmancipation in Information Systems Implementation: A Case Study in an NHS Trust Hospital," paper presented at the Critical Management Studies Conference, Manchester, 1999 (available online at http://www.mngt.waikato.ac.nz/ejrot/ cmsconference/documents/Information\%20Knowledge/Waring_Manchester.pdf).

Whitley, E. A. "Habermas and the Non-Humans: Towards a Critical Theory for the New Collective," paper presented at the Critical Management Studies Conference, Manchester, 1999a (available online at http://www.mngt.waikato.ac.nz/ejrot/cmsconference/documents/ Information\%20Tech/Habermas\%20and\%20the\%20non-humans.pdf).

Whitley, E. A. "Understanding Participation in Entrepreneurial Organizations: Some Hermeneutic Readings," Journal ofInformation Technology (14:2), 1999b, pp. 193-202.

Williams, R., and Edge, D. "The Social Shaping of Technology," Research Policy (25), 1996, pp. 865-899.

Wilson, F. A. "The Truth Is Out There: The Search for Emancipatory Principles in Information Systems Design," Information Technology and People (10:3), 1997, pp. 187-204.

Winner, L. Autonomous Technology: Technics-Out-of-Control as a Theme in Political Thought, Cambridge, MA: MIT Press, 1977.

Winner, L. "Upon Opening the Black Box of Technology and Finding it Empty: Social Constructivism and the Philosophy of Technology," Science, Technology and Human Values (18:3), 1993, pp. 362-378.

\section{ABOUT THE AUTHOR}

Ela Klecun is a lecturer in information systems at the London School of Economics and Political Science (LSE). She holds a Ph.D. in information systems from the LSE. Her research interests include health information systems, evaluation of information systems, and the application of critical theory and actor-network theory in the field of information systems. Ela can be reached by e-mail at e.klecun@1se.ac.uk or through her home page at http://is.lse.ac.uk/ staff/klecun. 